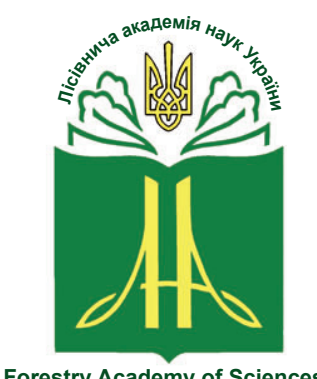

Forestry Academy of Sciences of Ukraine
Наукові праці Лісівничої академії наук України Proceedings of the Forestry Academy of Sciences of Ukraine http://fasu.nltu.edu.ua https://doi.org/10.15421/412016

Article received 2019.11.14

Article accepted 2020.06.04
ISSN 1991-606X print

ISSN 2616-5015 online

(a) $\triangle$ Correspondence author

Norbert Weber

norbert.weber@tu-dresden.de
Pienner Str. 8, 01737 Tharandt, Germany

UDC $630 * 97$

\title{
Visions, Missions and Strategies of selected International Forest Research Organizations
}

\author{
A. Koller ${ }^{1}$, N. Weber ${ }^{2}$
}

This paper provides a comparison of current visions, missions and strategies of three international forest research organizations: European Forest Institute (EFI), Center for International Forest Research (CIFOR) and International Union of Forest Research Organizations (IUFRO). Against the background of theoretical conceptions of visions, missions and strategies, a qualitative tabular content analysis is applied. A special focus lies on the thematic work areas of the organizations and their connection to the Sustainable Development Goals (SDGs).

Visions and missions provide an important guidance for employees and other people in the organization, but also for communication to outsiders. Within strategies, Non-Profit Organizations can define their mission and vision as well as strategic goals. Recent missions and visions of EFI, CIFOR and IUFRO are analyzed with a textual analysis, while for their strategies a summarizing content analysis is used.

The comparison discloses differences between the three organizations with regard to their orientation towards societal impact and/or advancement of science. However, all of them strive for improving living conditions for people. CIFOR clearly focuses on the SDGs and covers all of them, while IUFRO and EFI do this only partially. Except for doublings, EFI and IUFRO together address 12 SDGs out of 17 SDGs. This finding is especially important in the light of the current cooperation between EFI and IUFRO. Both organizations signed a Memorandum of Understanding in 2019, where they claim to account for achieving the SDGs by strengthening the role of forest conservation and sustainable forest management.

Key words: Research networks; international organizations; strategic planning; epistemic communities.

Introduction. In a globalized and rapidly changing world, forests are facing numerous expectations and threats. Climate change, illegal trade of wood and invasive species as well as land use changes have an influence on forest areas and ecosystems. Population growth and urbanization place increasing demands on forests and the ecosystem services they are providing. For effectively addressing the challenges of global change, it is necessary to understand these challenges and to find solutions. That is why, in addition to national organizations, forest research networks and organizations are occurring on regional and global level. The International Organization of Forest Research Organizations (IUFRO) was founded in 1892 already, while both the Center for International Forestry Research (CIFOR) and the European Forest Institute (EFI) were established in 1993.

Two of these organizations, i.e. EFI and CIFOR, recently announced their collaboration to support sustainable development and the United Nations Sustainable Development Goals (SDGs). On May 24 2019, CIFOR and EFI signed a Memorandum

\footnotetext{
1 Alexandra Koller - Graduate Student in the Master Programme Forest Sciences at Technische Universität Dresden, Pienner Str. 8, 01737 Tharandt, Germany, Tel. +49-351-463-31811, E-mail: alexandra.koller@tu-dresden.de ORCID https://orcid.org/0000-0001-7072-4619.

2 Norbert Weber - Prof. Dr., Professorship of Forest Policy and Forest Resource Economics, Technische Universität Dresden, Pienner Str. 8, 01737 Tharandt, Germany, Tel. +49-351-463-31828, E-mail: norbert.weber@tu-dresden.de ORCID https://orcid.org/0000-0001-7179-9364.
} 
of Understanding explicitly listing the following areas of priority collaboration (European Forest Institute, 2019b): a) The role of forest conservation and sustainable forest management for achieving the SDGs; b) Climate smart forestry and bioeconomy for mitigation and adaptation to climate change and their contribution to the Paris Agreement targets; c) Global forest governance.

The sustainable development goals are an important tool to face the problems of globalization and global change in the social, economic and ecological dimension. They were introduced by the United Nations in 2015 in the 2030 Agenda for Sustainable Development (United Nations General Assembly, 2015).

The objective of this paper is to contrast and compare current missions, visions and strategies of the selected forest research organizations. Both a summarizing and an inductive content analysis after Mayring \& Fenzl (2019) are applied to provide an overview as well as to develop a tabular analytical scheme.

Data and Methods. Selected organizations. The European Forest Institute is an international organization with a pan-European focus, uniting 120 Associate and Affiliate Member organizations in 38 countries. Its headquarters are located in Joensuu, Finland, with regional offices in Barcelona, Bordeaux, Bonn and Brussels. Besides, EFI has project offices in Malaysia and China. EFI has its work field in conducting research and providing policy support based on forestrelated research (European Forest Institute, 2019a). Advocacy activities have been intensified since 2010 . A specialty of EFI is the high-level forum on forests called Think Forest where policy makers and forest scientists convene in a science-policy dialogue.

The Center for International Forestry Research is part of the Consultative Group on International Agricultural Research (CGIAR), a global research partnership that aims to reduce poverty, enhance food and nutrition security, as well as to improve natural resources (Consultative Group on international Agricultural Research, 2019). CGIAR, constituting the roof organization of CIFOR, laid great emphasis on developing a «future vision, goal, mission and strategy» (CGIAR, 2000). As a non-profit, scientific institution, CIFOR leads the CGIAR Research Program on Forest, Trees and Agroforestry. In addition to the headquarters of CIFOR in Bogor, Indonesia, offices are located in Nairobi, Yaounde, Lima and Bonn. CIFOR works in more than 50 countries mostly in the southern hemisphere, e.g. Brazil, the Democratic Republic of Congo and Mozambique, parts of Asia and the Russian Federation. CIFOR states to conduct innovative research, to develop their partners' capacity and to engage in a dialogue with all stakeholders (Center for international Forestry Research, 2019).

The International Union of Forest Research Organizations is a member of the International Science Council (ISC), the latter constituting a non-profit, nongovernmental organization that unites international, national and regional scientific unions and associations.
Its members belong to the natural and the social sciences (International Science Council, 2019a). The Council's activities focus on three principal areas of work: (1) science-for-policy to communicate science that is relevant to policy, (2) policy-for-science to enable science to contribute in the international public domain, and (3) scientific freedom and responsibility (International Science Council, 2019b). IUFRO, the forest branch of ISC, counts almost 700 member organizations in over 125 countries and unites about 15.000 scientists. The headquarters are located in Vienna, Austria. It is the global leading network, both for forest science cooperation and research in forestfocused and forest-related topics. As a non-profit and non-governmental international network of scientists, it «enhances the understanding of the ecological, economic and social aspects of forests and trees» (www.iufro.org, accessed April 4, 2020; International Union of Forest Research Organizations, 2019).

Methods. In this paper, current strategies are examined that are displayed at the official websites of IUFRO, CIFOR and EFI. The regarded visions and missions in all documents are introduced by the caption «Vision» or «Mission».

For the strategies of each organization, a summarizing content analysis is used. In this qualitative content analysis method after Mayring \& Fenzl (2019), the content of a document is paraphrased and generalized. Furthermore, an inductive content analysis is used. For this method categories based on the document are set up. In a second step the content of the document can be assigned to these deductive developed categories. A distinction is made between two categories, i.e. «societal impact - oriented» and «science - centered», where the visions and missions are assigned to. For categorization of the work areas of the strategies, the SDGs from «The 2030 Agenda for sustainable Development» of the United Nations General Assembly (2015) are used.

Current state of research on strategies, visions and missions. In this chapter, the authors give a definition of vision and mission, since the terms and their purpose are often unclear (Baetz \& Bart, 1996). For simplification the terms «vision» / «vision statement», as well as «mission» / «mission statement» are equated.

According to Slyusarenko (2015), the concept of «vision» can be defined «as a strategic vision of itself by any institution due to its capacity to most effectively and fully realize its own mission (purpose, generic calling) under certain institutional slogan (motto - short formulation of the main guiding idea, action program)». As stated by Collins \& Porras (1996) a vision should provide guidance on: a) The core ideologies: «(...) what we stand for and why we exist». They contain the core values and the core purpose of the organization; $b$ ) The envisioned future: «(...) what we aspire to become, to achieve, to create».

This is a bold goal that should be reached within 1030 years and a vivid description of what it will be like to achieve the goal.

While the core ideology remains unchanged, the envisioned future requires adaption and progress to 
be achieved. A core value is an intrinsic value for the people that work in an organization by which they can identify themselves and that is important for them. The core value is not formed by markets or other environmental factors but only by the inner beliefs of the company's leaders. The core purpose should guide and inspire an organization by showing the deeper and fundamental purpose of this organization (Collins \& Porras, 1996). A vision should be inspirational and easy to remember, so it should be no longer than twelve words (Raynor, 1998). In a similar vein, Papulova (2014) recommends vision statements in strategic managements to be easy to understand, easy to remember, positive, motivational, inspiring, attractive, challenging and future-oriented. For developing a vision, several ways are possible: (i) discovering by intuition, (ii) team approach, (iii) rational approach, (iv) adapting the vision of other subjects (Papulova, 2014).

Specifically for Non-Profit-Organizations (NPOs), a vision is «an organizational aim that guides strategies, policies and tasks; it is also a key source of cultural formation and sustainable management.» (Liao \& Huang, 2016: 21). There are two dimensions of vision, i.e. leadership philosophy and specific impression. Moreover, an organization's vision points to the beliefs and values, both of its leader(s) and the enterprise (ibid.). In contradiction to enterprises, for NPOs only few organizational strategies have been developed. One of these focuses on three key issues: (i) the public value to be created, (ii) the sources of legitimacy and support for the organization, and (iii) the operational capacity for delivering value (Liao \& Huang, 2016).

According to Pearce (1982) a mission statement has three components: a) The company's basic product or service; b) The primary market; c) The technology used for the production and delivery of the product or service.

In the case of NPOs there is no market in the traditional sense, but still an addressee that shall receive the product or service provided. Unlike the vision, the mission is shaped by inside and outside claimants. The internal input comes from f.e. the executive officers as well as the employees. The external input is given by customers, competitors, governments, general public and others (Pearce, 1982). Raynor (1998) puts it even simpler: The mission of an organization should define its core competencies and values.

There is an overlapping between the definition of «mission» from Raynor (1998) and Pearce (1982): both agree that a company's mission includes its core competencies, the basic product or service it delivers for the primary market. But while Raynor (1998) assigns a company's core values to the mission, Collins \& Porras (1996) assign it to the vision. This example shows that there are many views what a vision and mission should contain. The authors agree with the opinion of Raynor (1998) that different definitions of vision and mission are equally useful in their contexts.

In their meta-analysis, covering 20 years of research on mission statements, Desmit et al. (2011) summarize frequently cited benefits. Mission statements are «providing a sense of the organizations's direction and purpose», «focusing the allocation of organizational resources», «communicating effectively with important internal and external stakeholders», and «describing the values of the organization that will guide and inspire organizational members».

Obviously, there are strong linkages between visions and missions. Normally, missions are created from visions, but that is not always the case. While the vision of an organization should describe how it adds value to society, the mission tells what it will do for external clients and society that these goals will be achieved (Moore et al., 2011). Hence, a mission is easier recognized than a vision. «But when the vision of an organization is recognized, it will help clarify its mission and its planning efforts. Without vision, there cannot be a mission» (Taiwo et al., 2016). Other authors claim that the main difference between these two concepts are the temporality and the order of application. Notwithstanding, to ensure the success and the survival of an organization, they should «contribute to positive societal-level impact» (Moore et al., 2011: 22) and be consistent with each other (López-Morales \& Ortega-Ridauro, 2016).

In a company's strategy specific goals are defined that drive actions to achieve the vision (Raynor, 1998). Based on the vision, a strategy has a set time frame, where the goals should be achieved. Within a strategy, a company can define its mission and vision as well as strategic goals. Strategies are necessary for Non-Profit Organizations for several reasons: increasing complexity, heterogenic stakeholders, discontinuity, technological change, pressure in competition and privatization, demand of constituents, increasing pressure for interaction, cooperation, professionalization (Schneider et al., 2007).

With regard to the linkages between visions, missions and strategies, Papulova (2014) puts it simply as following: «Vision and mission should explain why we chose the specific strategy«.

Vision, mission, strategy and action are the four components of strategic planning (Taiwo et al., 2016). Obviously, these three catchwords found entry into the documents of the selected organizations in recent years only. For instance, in an article where leaders of the three mentioned organizations presented their views and plans, the words "vision» and «strategy» are mentioned only once while «mission» does not occur at all (cf. Burley et al., 2001).

Results. Summary of the Strategy of EFI. The strategy of EFI (European Forest Institute, 2016) comprises six pages, a cover sheet and a decorative reverse side. The headings are as following: Connecting knowledge to action; Global context; Thematic framework; Strategic goals; Strategic activities.

Vision and mission of EFI are located on the first page «Connecting knowledge to action» of the document. The organization is introduced with its Main Themes, i.e. Bioeconomy, Resilience and Governance, and its Strategic Goals. 
The Global Context highlights the importance of forests for a circular, biobased society. The circular biobased economy is necessary for a sustainable future that is threatened by factors of global change caused by fossil-based economy.

The Thematic Framework explains the need of research in the fields of Bioeconomy, Resilience and Governance. According to EFI, the European bioeconomy relates to other factors like the international policy framework and the dynamics of global biomass demand by globalization. Interdisciplinary, crosssectoral research is needed to identify markets, products, policies and forest resources. The global change and urbanization have a big impact on the socio-ecological resilience of Europe. It is necessary to connect forest science with other land-use disciplines and urban studies to maintain intact, sustainable used forests and landscapes in an urbanized global connected Europe. Another threat to the European forests is the increasing conflict around land resources. EFI also supports forest governance in a changing environment. A new programme called NewGo! was deliberately established to provide «a platform to collaborate with other global international organisations like CIFOR and ICRAF and networks like IUFRO» (European Forest Institute, 2019c).

The thematic framework is meant to help EFI to achieve its strategic goals. Under 'Strategic Goals' each goal and its relevance to build a circular biobased economy is explained in detail. EFI wants to build a European forest research and innovation area, to inform policies, to address societal challenges and opportunities and to raise the awareness in society of the importance of forests (Fig. 1).

Under 'Strategic Activities', advocacy, research and foresight, knowledge networking, capacity building and building bridges are listed. These activities should contribute to the achievement of the strategic goals.

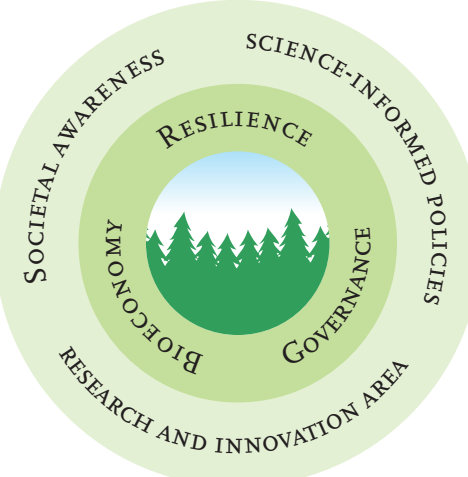

Figure 1: Strategic goals and thematic framework of the EFI Strategy 2025

Source: https://efi.int/sites/default/files/files/about/ efi_strategy2025_14112016.pdf

Summary of the Strategy of CIFOR. The strategy of CIFOR (Center for International Forestry Research, 2016) includes 40 pages in total. The first six pages contain a cover page, a contents page, list of figures, tables and boxes as well as a list of abbreviations. The chapter headlines of the strategy are: Introduction; CIFOR's aspirations; How we work; Thematic work areas; CIFOR's outcomes and impacts; Implementation and geographic focus.

In the introduction CIFOR explains the background of the strategy. In view of the Sustainable Development Goals (SDGs) and the Paris Agreement from 2015, CIFOR had to revise and adapt its previous strategy that would have ended 2018. The updated strategy includes the integrated landscape approach and shows a strong connection to the SDGs.

CIFOR specifies the vision, mission and values that the organization relies on. The values are concretized as following: Commitment to impact; innovation and critical thinking: integrity and professionalism; respect and collaboration.

How we work highlights CIFOR's principles and thematic work areas, CIFOR's theory of change, and CIFOR's three pillars: (1) Research for impact, (2) Capacity development, (3) Outreach and engagement. The thematic work areas are connected to CIFOR's theory of change, their pillars and related SDGs. According to its theory of change, CIFOR wants to contribute to reduced poverty, improved food and nutrition security, and improved natural resource systems and ecosystem services through demanddriven research that leads to knowledge-based policy and practices.

To use its resources most efficiently, CIFOR focuses on six thematic work areas that the organization believes have the greatest impact potential (Fig. 2). Each of the thematic work areas has linked sub-themes where the research goals are specified. The thematic work fields relate to different SDGs so that a total of 16 SDGs can be covered. Adding the leading role of CIFOR in the Global Landscape Forum, the SDG 17: Partnership on all goals is addressed. Consequently, CIFOR includes all 17 SGDs into their strategy.

The theme Forests and human well-being focuses on improvement of people's livelihoods and wellbeing through forest use and conservation. The natural resources of forests shall help reducing poverty in developing countries. The research aims to inform and influence forest policy on the regional and global level.

Sustainable landscapes and food investigate the role of forest foods for improved nutrition and food security as well as the interaction of forest ecosystem services and agriculture. CIFOR aims to study and describe the importance of forest products, forest attributes and tree-based agricultural systems for healthy and diverse diets.

In Equal opportunities, gender, justice and tenure CIFOR seeks to integrate all genders in their research and action initiatives. The organization wants to understand the factors that inhibit rights transfer to indigenous people and other minorities and to evaluate the effects of this devolution on forests, livelihoods and local governance, including women's participation.

The topic of Climate change, energy and lowcarbon development is the two-sided relationship of 
forests and agricultural land with carbon: Forestry and agriculture can be sinks but also sources of carbon dioxide. Further research is needed to understand the interactions between forests, other landscapes and climate, to reduce the impacts of climate change and to protect local livelihood as well as ecosystem services.

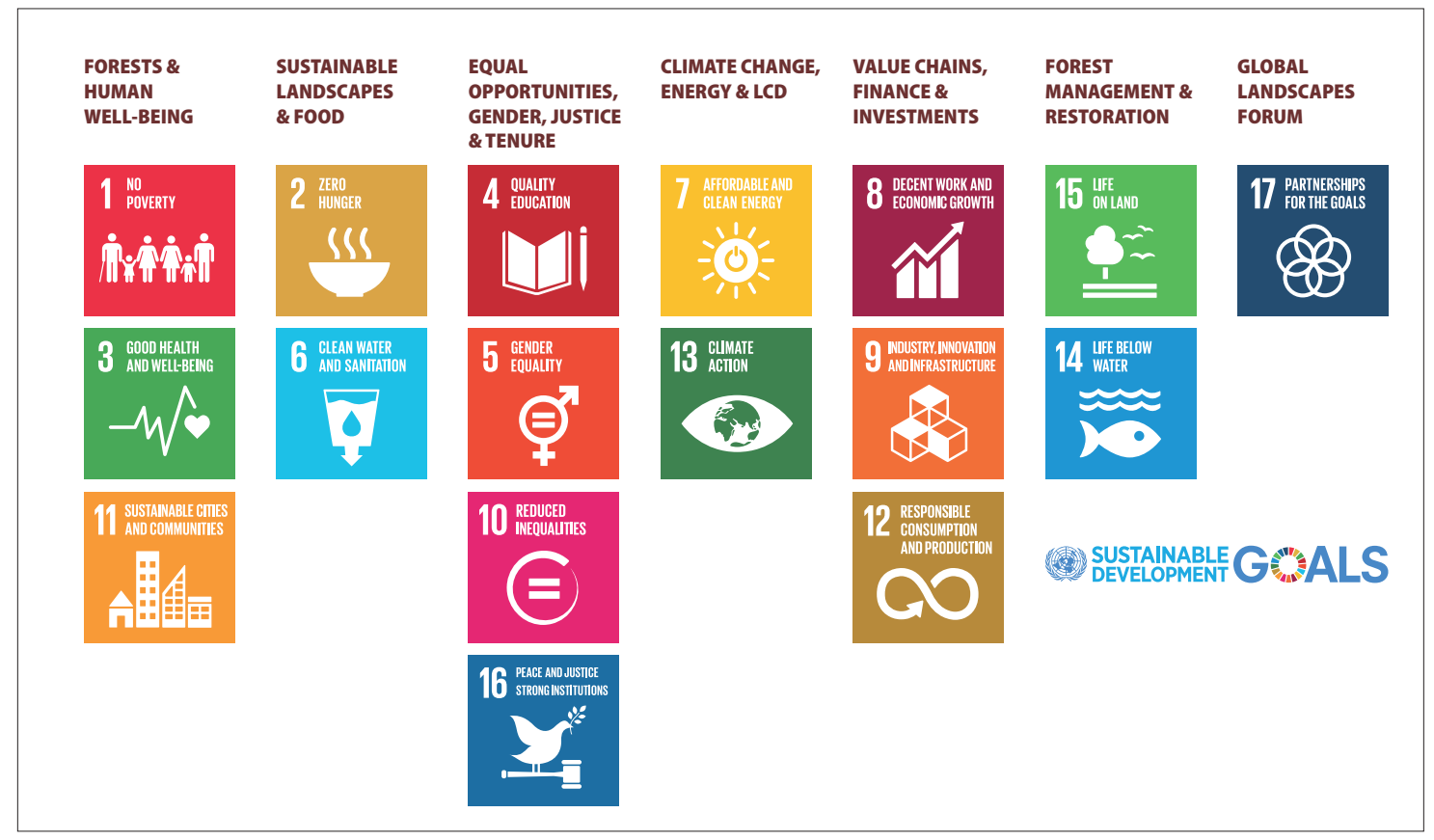

Figure 2: SDGs addressed by CIFOR Strategy

Source: http://www.cifor.org/publications/pdf_files/Books/CIFORStrategySummary2016.pdf

Value chains, finance and investments faces the challenges of economic growth. Social inclusion and sustainability must be maintained by more sustainable value chains, and by support of small- and mediumscale enterprises. So they can compete in a global industry, while aiming at high environmental and social standards. CIFOR wants to support sustainable public, private and public-private governance arrangements along with inclusive business models.

In the field of Forest management and restoration, CIFOR mainly conducts research on carbon-rich wetlands, mangroves and peat lands, regarding their role in climate mitigation, nutrient cycling and other ecosystem services. For improved forest management and restoration, CIFOR investigates in diversified forest management and forest landscape restoration.

CIFOR's outcomes and impacts lists measurable key impacts that should result within the 10 years of the strategy. The table links indicators with associated work areas and SDGs.

Implementation and geographic focus describes how CIFOR wants to achieve the strategic outcomes in which ecological regions. Each thematic work area has a research team. Additionally, a seventh research team carries out the monitoring, evaluation, assessment and coordination of approaches and data management and a further team is established for outreach and engagement.

Summary of the Strategy of IUFRO. The strategy of IUFRO (International Union of Forest Research Organizations, 2015) comprises 28 pages in total, of these 17 pages of text. Pictures related to forests are embedded in the text as well as on the front cover and on the last two pages.

On the first pages, the readers are provided with a foreword, a table of contents and the executive summary in four different languages. The main content is structured as following: Vision/Mission/Core Values; Overview; Five Themes; Institutional Goals.

The Overview presents the background behind the five chosen themes. IUFRO wants to provide a knowledge base to face the main challenges forests are experiencing and thereby promote sustainable development and human well-being. Each theme relates to the threats affecting forests. The themes are briefly explained in the overview.

Each Theme features a problem statement, where a short introduction to the topic is given, followed by a justification why research is necessary, and emphasis areas, where concerted research targets and areas are proposed.

The Topic of Theme 1: Forests for People is the changing relationship between people and forests and the emerging consequences for social values of forests, people's livelihood and quality of life depending on forests. It is important to understand the drivers of change to develop a more sustainable relationship between people and forests, to improve management of forests and forest-related landscapes, to enhance forest ecosystem services and to inform policy makers for policy decisions that lead to a fair delivery of forest benefits for all people. The four emphasis areas are: (1) Forests for livelihood, (2) forests for quality of live, (3) Social values of forests and (4) forest governance. 
Theme 2: Forests and Climate change deals with mitigation and adaptation options of forests mitigation and adaption options of forests to climate change. Mitigation and adaption strategies are an important research field to ensure forest ecosystems and its services. The emphasis areas are (1) Impacts of climate change on forest ecosystems and forest-dependent people, (2) Feedbacks between climate, land cover, forest disturbance and provision of energy and water, (3) Biodiversity and invasive species, (4) Mitigation and adaption strategies.

Theme 3: Forests and forest-based products for a greener future circle around woody biomass and ecosystem services as important products of forests that will play a key role in the emerging bio-based economy. The products and services of forests and their potential are still undervalued and not enough understood. The three emphasis areas (1) New forest products and services, (2) Use of forest-based products and services and (3) Valuing forests and their ecosystem services shall help in understanding the role of forest products and services for the future well-being of the world's population.

In Theme 4: Biodiversity, Ecosystem Services and Biological Invasions the focus lies on the biodiversity associated with forests and its threads from globalization, climate change and invasive species. The effects of forest and biodiversity loss are poorly understood and demand further research in this matter. Another important research area is the development of conservation strategies for forest biodiversity and associated forest ecosystem services. The emphasis areas of this theme are: (1) Trends, causes and impacts of biodiversity loss at all levels, (2) Landscape-level strategies for biodiversity conservation and sustainable use, (3) Ecosystem services, (4) Contribution of restoration to the conservation on and sustainable use of biodiversity and ecosystem services and (5) Biological invasions threatening biodiversity and ecosystem services of forests.

The areas of Theme 5: Forest, soil and water interactions are the ecosystem services of the forest providing fresh water, water conservation, water regulation and soil protection. The integrity of these ecosystem services is put at risk by deforestation, forest degradation, land-use changes and climate change. It is necessary to find multi-sectoral and integrated landscape approaches to stop the loss of these ecosystem services and to meet the growing demands. For a better understanding and protection of the resources more research on the interactions between forest, water, soil and climate is needed. Four different emphasis areas are listed: (1) Macro-level land management and impacts on the water cycle, (2) Climate change adaptation and mitigation, and interactions with water yield and quality, nutrients and soil resources, (3) Forest ecosystems and water conservation and (4) Forest ecosystems and disaster prevention and reduction.

The topic Institutional Goals describes areas in which IUFRO wants to perform better or to be more active. To reach these goals IUFRO is going to diversify its funding base by creating a fundraising culture within IUFRO's decision-making bodies, develop a fundraising strategy and to strengthen its institutional capacity for donor intelligence and fundraising. Three different institutional goals are defined. Each of them has three different objectives with specific actions that shall lead to fulfillment of the respective goal. The goals are: Goal 1 - Research excellence: Strive for quality, relevance and synergies; Goal 2 - Network Cooperation: Increase communication, visibility and outreach; Goal 3 - Policy impact: Provide analysis, insights and options.

Comparison of Strategies, Visions and Missions of the Selected Organizations. Comparing the content of the strategies each of the organizations states their visions, missions and thematic work areas in the strategy document. IUFRO and EFI display strategic/institutional goals, while CIFOR lacks them. Core values are disclosed by CIFOR and IUFRO. Outstanding about the strategy of CIFOR is that it includes implementation plans and key measurements for the success of their goals in the strategy. EFI provides an implementation plan, too, but in an extra document.

In the tabular analysis (Tab. 1,2,3) it is recognizable that EFI has the shortest vision, mission and strategy. Due to the length of the strategies of CIFOR, 40 pages, and IUFRO, 28 pages, both organizations have an executive summary. CIFOR's executive summary is an extra document with 12 pages available in English, French, Indonesian and Spanish while IUFRO's executive summary counts one page. The available languages are English, French, German and Spanish. The strategy covering the shortest time period is the strategy of IUFRO with four years. The strategies of CIFOR and EFI were designed for ten years, both the period 2016-2025. While IUFRO states its vision and mission on the official website and strategy, CIFOR's and EFI's vision and mission are only included in the organization's strategies.

Obviously, there is an overlapping of the thematic areas of CIFOR and IUFRO. Both aim at «Forests and climate change» and on the «Interactions between forests and humans». A linkage between EFI and IUFRO can be seen in the topic «Bioeconomy». EFI and CIFOR have no overlapping thematic work areas. The results of the inductive analysis on the categorization of the work fields from EFI and IUFRO into different SDG goals can be found in table 4 (EFI's work areas and associated SDGs), and table 5 (IUFRO's work areas and associated SDGs).

Some goals like «SDG 4: Quality education» or goal «SDG 5: Gender equality» are not included in both organizations' working areas. EFI's working areas can be assigned to seven and IUFO's working areas to nine SDGs.

SDGs $8,12,13$ and 15 are addressed both by EFI and IUFRO. In the thematic work areas of IUFRO the SDGs 13 and 15 can be assigned each to two work areas. Except for the doublings within and between the organizations work areas EFI and IUFRO together can cover twelve out of 17 SDGs. 
Comparison of the strategy of EFI, CIFOR and IUFRO

\begin{tabular}{|c|c|c|c|}
\hline Examined feature & EFI & CIFOR & IUFRO \\
\hline Number of pages & 8 & 40 & 28 \\
\hline Available languages & English & English & English \\
\hline Short/Executive summary? & No & Yes & Yes, in the first pages of strategy \\
\hline Available languages & - & $\begin{array}{l}\text { English, French, } \\
\text { Indonesian, Spanish }\end{array}$ & $\begin{array}{l}\text { English, French, } \\
\text { German, Spanish }\end{array}$ \\
\hline Number of pages & - & 12 & 1 \\
\hline Implementation Plan? & Yes & Yes & No \\
\hline Period & $2016-2025$ & $2016-2025$ & $2015-2019$ \\
\hline Thematic work areas & $\begin{array}{l}\text { (1) Resilience; } \\
\text { (2) Bioeconomy; } \\
\text { (3) Governance. }\end{array}$ & $\begin{array}{l}\text { (1) Forests and human } \\
\text { well-being; } \\
\text { (2) Sustainable landscapes and } \\
\text { food; } \\
\text { (3) Equal opportunities, gender, } \\
\text { justice and tenure; } \\
\text { (4) Climate change, energy and } \\
\text { low-carbon development; } \\
\text { (5) Value chains, finance and } \\
\text { investments; } \\
\text { (6) Forest management and } \\
\text { restoration. }\end{array}$ & 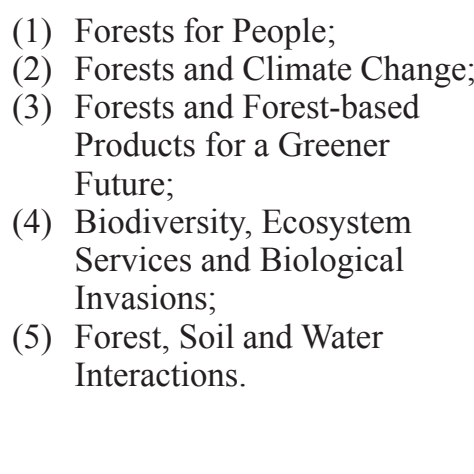 \\
\hline
\end{tabular}

Table 2

Comparison of the vision of EFI, CIFOR and IUFRO

\begin{tabular}{lccc}
\hline Examined feature & EFI & CIFOR & IUFRO \\
\hline Number of words & 9 & 17 & 17 \\
\hline Wording & $\begin{array}{c}\text { A world where forests } \\
\text { significantly contribute to } \\
\text { sustainable wellbeing }\end{array}$ & $\begin{array}{c}\text { CIFOR envisions a more } \\
\text { equitable world where forestry } \\
\text { and landscapes enhance the } \\
\text { environment and wellbeing } \\
\text { for all }\end{array}$ & $\begin{array}{c}\text { The leading global network } \\
\text { for forest-related research } \\
\text { that serves the needs of all } \\
\text { forest researchers and } \\
\text { decision-makers }\end{array}$ \\
\hline Found on website? & Yes, but other wording & No & Yes \\
\hline Found in strategy? & Yes & Yes & Yes \\
\hline
\end{tabular}

Comparison of the mission of EFI, CIFOR and IUFRO

Table 3

\begin{tabular}{lccc}
\hline \multicolumn{1}{c}{ Examined feature } & EFI & CIFOR & IUFRO \\
\hline Number of words & 4 & 33 & 25 \\
\hline Wording & $\begin{array}{c}\text { Connecting } \\
\text { knowledge } \\
\text { to action }\end{array}$ & $\begin{array}{c}\text { CIFOR advances human well-being, } \\
\text { equity and environmental integrity } \\
\text { by conducting innovative research, } \\
\text { developing partners' capacity and } \\
\text { actively engaging in dialogue with all } \\
\text { stakeholders to inform policies and } \\
\text { practices that affect forests and people }\end{array}$ & $\begin{array}{c}\text { IUFRO advances research } \\
\text { excellence and knowledge } \\
\text { sharing and fosters the } \\
\text { solutions to forest-related } \\
\text { challenges for the benefit of } \\
\text { forests and people worldwide }\end{array}$ \\
\hline Found on website? & No & No & Yes \\
\hline Found in strategy? & Yes & Yes & Yes \\
\hline
\end{tabular}


Table 4

EFIs work areas and associated SDGs

\begin{tabular}{ll}
\hline Work area & \multicolumn{1}{c}{ Associated SDGs } \\
\hline Bioeconomy & $\begin{array}{l}\text { SDG 8: Decent work and economic } \\
\text { growth }\end{array}$ \\
& $\begin{array}{l}\text { SDG 12: Responsible consumption } \\
\text { and production } \\
\text { SDG 13: Climate action }\end{array}$ \\
\hline Resilience & $\begin{array}{l}\text { SDG 9: Industry, innovation and } \\
\text { infrastructure } \\
\text { SDG 11: Sustainable cities and } \\
\\
\text { communities } \\
\text { SDG 15: Life on land }\end{array}$ \\
\hline Governance & $\begin{array}{l}\text { SDG 16: Peace, justice and strong } \\
\text { institutions }\end{array}$ \\
\hline
\end{tabular}

IUFROs work areas and associated SDGs

\begin{tabular}{ll}
\hline \multicolumn{1}{c}{ Work area } & \multicolumn{1}{c}{ Associated SDGs } \\
\hline Forests for people & $\begin{array}{l}\text { SDG 1: No poverty } \\
\text { SDG 2: Zero hunger } \\
\text { SDG 3: Good health and well } \\
\text { being }\end{array}$ \\
\hline $\begin{array}{l}\text { Forests and climate } \\
\text { change }\end{array}$ & SDG 13: Climate action \\
\hline $\begin{array}{l}\text { Forests and } \\
\text { forest-based products } \\
\text { for a greener future }\end{array}$ & $\begin{array}{l}\text { SDG 8: Decent work and } \\
\text { SDG 12: Responsible } \\
\text { consumption and production }\end{array}$ \\
\hline $\begin{array}{l}\text { Biodiversity, } \\
\text { Ecosystem Services } \\
\text { and Biological }\end{array}$ & $\begin{array}{l}\text { SDG 14: Life below water } \\
\text { SDG 15: Life on land }\end{array}$ \\
\hline $\begin{array}{l}\text { Forest, soil and water } \\
\text { interactions }\end{array}$ & $\begin{array}{l}\text { SDG 6: Clean water and } \\
\text { Sanitation } \\
\text { SDG 13: Climate action }\end{array}$ \\
& SDG 15: Life on land \\
\hline
\end{tabular}

Regarding the visions of the forest research organizations two divisions are noticeable. While CIFOR and EFI focus on forests contributing to a well-being for all, IUFRO primarily wants to serve the needs of researchers and politicians. Consequently, the addressees of the visions are different. While EFI and CIFOR are focusing on the whole humanity with phrases like «a world» or «for all», IUFRO speaks specifically to «all forest researchers and decisionmakers». Regarding the inductive categories 'societal impact - oriented' and 'science - centered' IUFROs vision can be classified as belonging to the latter category while the visions of the other two organizations are primarily societal impact - oriented.
In its mission, IUFRO changes the addressees and wants to achieve benefits for people. Still IUFRO has a more research - focused approach: In this mission statement, three words out of 25 have research-related meaning, while CIFOR dedicates one word out of 33 to research. In IUFRO's mission human wellbeing is also an aim of their activities, but mentioned on last position, after the benefits for forests. Therefore, IUFROs mission is classified as science-centered. In EFI's mission statement, research plays a superior role with one out of four words. But in this vision drawing conclusions of research for policy is seen as important, too. EFIs mission can be ranged as science-centered, too. Regarding CIFOR's mission, at least with regard to the wording, human wellbeing is seen more important than conducting research. The activities are mainly focusing on the human dimension, i.e. developing capacities of CIFOR's partners and engaging in a dialoge with stakeholders about topics that affect as well forests as people. The mission of CIFOR is clearly societal impact - centered.

In conclusion, IUFRO displays a vision that is different from the other two organizations. However, its thematic work fields overlap with CIFOR and EFI, while EFI's and CIFOR's working areas do not overlap despite a similar vision. With regard to the mission, the situation is different. In each of the missions, science related activities are mentioned. Benefits for society are part of the missions of CIFOR and IUFRO, but not explicitly mentioned in EFI's mission. Out of the organizations, CIFOR has the most societal - oriented mission.

Discussion. Discussion of Methods. Since in our opinion this paper is the first one comparing visions, missions and strategies of forest research organizations, own approaches had to be developed. Some authors already conducted research on mission and/or vision statements of organizations. Most of these studies aim at enterprises (e.g. Papulova, 2014, López-Morales \& Ortega-Ridaura, 2016, Taiwo et al., 2016). In their metaanalysis, Desmit et al. (2011) take a closer look at 20 years of research about the value of mission statements for organizations' performance. Others scholars are focusing on institutions of education. For example, 81 private and public schools were compared regarding their vision or missions with a content analysis (Boerema, 2006). In a similar vein, Slyusarenko (2015) compared visions of world-class universities with their missions.

In a study with a setting more related to forests, Campagna \& Fernandez (2007) analyzed vision and mission statements of 24 environmental organizations mostly working in the field of wildlife and natural habitats. The authors therefore conducted a textual analysis against a framework of ethos, logos and pathos as three distinct value judgements on nature.

However, the goal of the mentioned study is different than in the present paper. Campagna \& Fernandez (2007) performed a quantitative analysis on how the organizations portray nature. Moreover, no strategies are included in the considerations. In the present 
paper, an analysis focused on qualitative aspects is conducted. Missions and visions are analyzed with a textual analysis regarding the addressees, but for the analysis of the strategies a framework was not enough. The authors therefore select a tabular analysis and a summarizing content analysis as well as a deductive content analysis after Mayring \& Fenzl (2019). The summarizing and deductive content analysis are techniques of the qualitative content analysis according to Mayring (2015). For comparison with other surveys it should be noted that not all of the eight steps of the full qualitative content analysis are performed in this paper as only the analysis techniques of the qualitative content analysis after Mayring (2015) have been applied.

Discussion of Results. Thematic Work Areas and Sustainable Development Goals. As shown in the results, CIFOR clearly focuses on the SDGs, while IUFRO and EFI do this only partially. CIFOR covers all SDGs due to the deliberate goal of its strategy to integrate them into their research. The purpose behind this could lie in CIFORs working radius. CIFOR works in the southern hemisphere, while IUFRO operates worldwide and EFI more in the pan-European area. However, many of the SDGs are not achieved yet in the global south. For example, in least developed and landlocked developing countries at least one quarter of workers live in extreme poverty, despite having a job. Two thirds of undernourished people worldwide life in sub-Saharan Africa and southern Asia (United Nations, 2019). Many countries of this region are part of the working radius of CIFOR (Center for International Forestry Research, 2019). Therefore it is a top priority for CIFOR to work towards achieving the SDGs with the help of research on forests, trees and agroforestry as well as capacity building and engaging in a dialogue with all stakeholders.

Except for the doublings, EFI and IUFRO together address twelve SDGs out of 17 SDGs. This is especially important considering the current development between EFI and IUFRO. As already mentioned, both organizations signed a Memorandum of Understanding, where they claim to account for achieving the SDGs by strengthening the role of forest conservation and sustainable forest management (European Forest Institute, 2019b). This seems to be a promising step, as this cooperation covers twelve SDGs assigned to the work areas of both organizations and an additional SDG, «SDG 17: Partnership for the goals». This makes a total of thirteen included SDGs. Besides, IUFRO must develop a new strategy with actualized fields of work because the past strategy ran out in 2019. The new strategy might provide a chance to incorporate more SDGs into the work of IUFRO.

Vision and Mission. First, it must be emphasized that each of the forestry research organizations has a vision and mission stated in their strategy, at least partly displayed on their websites. Some other international environmental research organizations, like e.g. the Intergovernmental Science-Policy Platform on Biodiversity and Ecosystem Services (IPBES), lack a vision and mission. According to Bridgewater et al. (2019) «[t]here is a need for a more explicit and formal IPBES vision and mission that is linked to an overall strategic framework, (...). The lack of a unified vision and mission results in different views and expectations among the various experts, members, partners and other stakeholders taking part in the Platform regarding what IPBES is, what it is trying to achieve and where it should focus.» This statement illustrates that vision and mission are an important guidance for employees and other people in the organization, but also for communication to outsiders. This circumstance is also acknowledged by other authors like Baetz \& Bart (1996) or Collins \& Porras (1996).

The vision and mission of CIFOR are societal impact - oriented. This could be due to the same reason as CIFOR works towards all SDGs. Their work field lies in the southern hemisphere, therefore it is a top priority to secure the well-being of people before other activities can be carried out successfully.

EFI's vision is societal impact - oriented but the mission statement is science-centered. The organization mostly works in the pan-European region, consisting of more or less industrialized countries. It is a common assumption that the wellbeing of people in industrialized countries is higher than in developing countries. According to the Cambridge advanced learner's dictionary «wellbeing» is defined as «the state of feeling healthy and happy» (Mcintosh, 2013). In neither of the visions and missions of the organizations, the term "wellbeing» is defined. For easier comparison, the following discussion is based on wellbeing as state of health, because in the SDGs wellbeing is assigned to SDG 3 that also includes human health. As showed in the examples, the wellbeing in the European region is higher than in development countries. This could be a possible explanation for the science-centered mission of EFI.

Despite working worldwide, IUFROs vision and mission are science-centered as well. Regarding the communication to outsiders, with its vision and mission IUFRO at first sight seems to focus on research for researchers and politicians only. However, a closer look at the strategy of IUFRO makes clear that one of the five research areas is directly related to human wellbeing: «Forests for People» with two out of four emphasis areas i.e. (1) Forests for livelihood and (2) Forests for quality of live. Other emphasis areas from the remaining four topics are indirectly inked to human wellbeing, for example impacts of climate change on forest ecosystems and forest-dependent people; use of forest-based products and services; ecosystem services; or forest ecosystems and water conservation. It remains to be seen if IUFRO incorporates the societal impactcentered view explicitly into their new vision and mission in the updated strategy for 2020.

For future research, it would be fruitful to assess (i) how the visions, missions and strategies have been modified and adapted to changing framework conditions along time; (ii) how they become visible in the manifold outputs of the organizations, e.g. 
publications, conferences and think tanks; and (iii) which kind of attention they receive from constituents, internal and external stakeholders, and how they are evaluated by these groups.

\section{References}

Baetz M.C., \& Bart C. K. (1996). Developing mission statements which work. Long Range Planning, 29 (4), 526-533. Retrieved from http://www.sciencedirect. com/science/article/pii/0024630196000441

Boerema, A. J. (2006). An Analysis of Private School Mission Statements. Peabody Journal of Education, 81 (1), 180-202. Retrieved from https://eric. ed.gov/?id=EJ733819

Bridgewater, P., Rosales, M., Beard D., Chaudharki K. P., Van Jaarsveld, A. S., Jenderedijan, K., ... Mulongoy, K. J. (2019). Review of the first work programme of the Intergovernmental SciencePolicy Platform on Biodiversity and Ecosystem Services (IPBES) Review report. Retrieved from https://ipbes.net/system/tdf/ipbes-7-inf-18_review. pdf?file $=1 \&$ type $=$ node $\&$ id $=29859$

Burley, J., Seppälä, R., El-Lakany, H., Sayer, J., \& Krott, M. (2001). Voicing interests and concerns: challenges for forest research. Forest Policy and Economics, 2, 79-88. Retrieved from https://pubag. nal.usda.gov/catalog/3059299

Campagna, C., \& Fernandez, T. (2007). A Comparative Analysis of the Vision and Mission Statements of International Environmental Organisations. Environmental Values, 16 (3), 369-398. https://doi. org/10.3197/096327107X228409

Center for International Forestry Research (2016). CIFOR Strategy 2016-2025. Stepping up to the new climate and development agenda. Bogor, Indonesia. Retrieved from http://www.cifor.org/publications/ pdf_files/Books/CIFORStrategy2016.pdf (accessed Nov 17, 2019)

Center for International Forestry Research (2019). About CIFOR. Retrieved from https://www.cifor.org/ about-cifor/ (accessed Dec 1, 2019).

Collins, J.C., \& Porras, J.I. (1996). Building your company's vision. Harvard Business Review (September-October), 65-77. Retrieved from https:// hbr.org/1996/09/building-your-companys-vision

Consultative Group on International Agricultural Research (2000). A Food Secure World For All: Toward a New Vision and Strategy for the CGIAR. TAC Secretariat/FAO, October 2000. Retrieved from http://www.fao.org/docs/eims/upload/215055/new vision_strategy_cgiar.pdf

Consultative Group on International Agricultural Research (2019). Research Centers. Retrieved from https://cgiar.org/research/research-centers/ (accessed Dec 1, 2019).

Desmit, S., Prinzie, A., Decramer, A. (2011). Looking for the value of mission statements: a meta-analysis of 20 years of research. Management Decision, 49, (3),
468-483. Retrieved from http://www.sciencedirect. com/science/article/pii/0024630196000441

European Forest Institute (2016). EFI Strategy. Connecting knowledge to action, Joensuu, Finland. Retrieved from https:/efi.int/sites/default/files/files/ about/efi_strategy2025_14112016.pdf (accessed Nov 17, 2019 )

European Forest Institute (2019a). About EFI. Retrieved from https://www.efi.int/about (accessed Dec 1, 2019).

European Forest Institute (2019b). EFI and CIFOR join forces. Retrieved from https://www.efi.int/articles/ efi-and-cifor-join-forces (accessed Jan 21, 2020).

European Forest Institute (2019c). EFI establishes new Governance programme. EFI News, 15 Nov 2019, Retrieved from https://www.efi.int/articles/efiestablishes-new-governance-programme, (accessed Apr 18, 2020)

International Science Council (2019a). About us. Retrieved from https:/council.science/about-us/ (accessed Dec 12, 2019).

International Science Council (2019b). What we do. Retrieved from https://council.science/what-we-do/ (accessed Dec 2, 2019).

International Union of Forest Resarch Organizations (2015). IUFRO Strategy 2015-2019. Interconnecting Forest, Science and People, Wien, Austria. Retrieved from https://www.iufro.org/fileadmin/material/science/divisions/toolbox/iufro-strategy-2015-2019.pdf (accessed Nov 17, 2019)

International Union of Forest Research Organizations (2019). The Organization. Retrieved from https:// www.iufro.org/discover/organization/ (accessed Dec 1, 2019).

Liao, K.-H., \& Huang I-S. (2016). Impact of Vision, Strategy, and Human Resource on Nonprofit Organization Service Performance. Procedia Social and Behavioral Sciences, 224, 20-27. https:// doi.org/10.1016/j.sbspro.2016.05.395

López-Morales, J.S., \& Ortega-Ridauro, I. (2016), International strategy of the 500 largest firms in Latin America: an analysis from its mission and vision. Problems and Perspectives Management (openaccess), 14 (3-3). https://doi.org/10.21511/ppm.14 (3-3).2016.06

Mayring, P. (2015). Qualitative Inhaltsanalyse. Grundlagen und Techniken. Beltz, Weinheim, Basel.

Mayring, P., \& Fenzl, T. (2019). Qualitative Inhaltsanalyse. In: Baur, N. \& Blasius, J. (Hrsg.), (pp. 633-648). Handbuch Methoden der empirischen Sozialforschung. Wiesbaden: Springer Fachmedien Wiesbaden.

Mcintosh C. (Hrsg.) (2013). Cambridge advanced learner's dictionary. Cambridge: Cambridge Univ. Press

Moore, S.L., Ellswortch, J.B., Kaufman, R. (2011). Visions and Missions: Are they useful? A quick assessment. Performance Improvement, 50 (6). 1524. https://doi.org/10.1002/pfi.20222 
Papulova, Z. (2014). The significance of Vision and Mission Development for Enterprises in Slovak Republic. Journal of Economics, Business and Management, 2 (1), 12-16. https://doi.org/10.7763/ JOEBM.2014.V2.90

Pearce, J.A. (1982). The Company Mission as a Strategic Tool. Sloan Management Review, 23 (3), 15. Retrieved from https://search.proquest.com/ docview/1302988171?\&imgSeq=1

Raynor, M.E. (1998). That vision thing: Do we need it? Long Range Planning, 31, (3), 368-376. Retrieved from https://www.econbiz.de/Record/that-visionthing-do-we-need-it-raynor-michael/10007353496

Schneider, J., Minning, C., Freiburghaus, M. (2007). Strategische Führung von Nonprofit-Organisationen. Bern: Haupt

Slyusarenko, O (2015). The Visions of World-Class Universities. Comparative Professional Pedagogy, 5 (2), 58-67. https://doi.org/10.1515/rpp-2015-0041

Taiwo, A.A., Lawal, F.A., Agwu, M.E.(2016). Vision and Mission in Organization: Myth or Heuristic Device? The International Journal of Business \& Management, 4 (3), 127-134. Retrieved from https:// www.researchgate.net/publication/312603042 Vision_and_Mission_in_Organization_Myth_or_ Heuristic_Device

United Nations General Assembly (2015). Transforming our world: The 2030 Agenda for sustainable development. A/RES/70/1. Retrieved from https://sustainabledevelopment.un.org/content/ documents $/ 21252030 \% 20$ Agenda $\% 20$ for $\% 20$ Sustainable\%20Development\%20web.pdf

United Nations (2019). The Sustainable Development Goals Report 2019, New York. Retrieved from https:// unstats.un.org/sdgs/report/2019/The-SustainableDevelopment-Goals-Report-2019.pdf

\section{Бачення, місії та стратегії окремих міжнародних лісових дослідних організацій}

\section{А. Коллер ${ }^{1}$, Н. Вебер²}

Кожна із лісових дослідних організацій має бачення і місію, викладені в їхній стратегії. Окремим міжнародним організаціям 3 дослідження навколишнього середовища, таким як, наприклад, Міжурядовій науково-політичній платформі з біорізно-

Александра Коллер - аспірант магістерської програми лісових наук Технічного університету у Дрездені, вул. Піннер, 8, 01737 Тарандт, Німеччина. Тел.: +49-351-463-31811. E-mail: alexandra.koller@tu-dresden.de ORCID https://orcid.org/00000001-7072-4619

Норберт Вебер - професор, доктор, професор лісової політики та економіки лісових ресурсів Технічного університету у Дрездені, вул. Піннер, 8, 01737 Тарандт, Німеччина. Тел.: +49-351-463-31828, E-mail:norbert.weber@tu-dresden.de ORCID https://orcid.org/0000-0001-7179-9364 маніття та екосистемних послуг (IPBES) не вистачає бачення і місії. Відсутність єдиного бачення i місії призводить до різних поглядів і очікувань серед різних експертів, членів, партнерів та інших зацікавлених сторін, які беруть участь у Платформі щодо того, що таке IPBES, чого вона намагається досягти і на чому вона повинна зосередитися. Це твердження показує, що бачення і місія $\epsilon$ важливим керівництвом до дії для співробітників та інших людей в організації, а також для спілкування 3 особами, які не належать до організації.

Наведено порівняння поточних поглядів, місій і стратегій трьох міжнародних організацій, які займаються дослідженнями лісів: Європейського інституту лісу (EFI), Центру міжнародних досліджень лісу (CIFOR) і Міжнародного союзу лісових дослідницьких організацій (IUFRO). На тлі теоретичних концепцій бачень, місій і стратегій застосовується якісний контент-аналіз. Особливу увагу приділено тематичним сферам діяльності організацій та їхньому зв'язку з Цілями Сталого Розвитку (Sustainable Development Goals - SDGs).

Бачення і місія $€$ важливим керівництвом до дій для співробітників міжнародних організацій, а також для спілкування з особами поза організацією. В рамках стратегій некомерційні організації можуть визначати свою місію і бачення, а також стратегічні цілі. Останні місії і бачення EFI, CIFOR i IUFRO проаналізовано за допомогою текстового аналізу, в той час як для їхніх стратегій використано узагальнюючий контент-аналіз.

Наведене порівняння розкриває відмінності між трьома організаціями щодо їх орієнтації на суспільний вплив і розвиток науки. Однак всі вони прагнуть поліпшити умови життя людей. CIFOR чітко фокусується на SDGs i охоплює всі цілі, в той час як IUFRO і EFI роблять це тільки частково. За винятком подвоєнь, EFI і IUFRO спільно розглядають 12 SDGs 317 SDGs. Цей висновок особливо важливий у світлі поточної співпраці між EFI і IUFRO. Обидві організації підписали Меморандум про взаєморозуміння від 2019 року, в якому вони стверджують, що відповідають за досягнення SDGs шляхом посилення ролі збереження лісів та ведення сталого лісового господарства.

Незважаючи на діяльність у всьому світі, бачення i місія IUFRO також зосереджені на науці. Що стосується спілкування з особами за межами організації, то баченням і місія IUFRO на перший погляд, здається, зосередженою на дослідженнях лише для дослідників і політиків. Однак більш уважний розгляд стратегії IUFRO показує, що одна із п'яти сфер досліджень пов'язана безпосередньо 3 добробутом людини: «Ліси для людей» 3 двома із чотирьох пріоритетних сфер, тобто (1) «Ліси для засобів існування» і (2) «Ліси для якості життя». Інші пріоритетні області з решти чотирьох побічно пов'язані з добробутом людей, наприклад, вплив зміни клімату на лісові екосистеми і людей, залежних від лісу; використання лісових товарів і послуг; послуги екосистем; лісові екосистеми і водозбере- 
ження. Ще невідомо, чи включить IUFRO своє соціальне бачення, зосереджене на впливах, в оновлену стратегію 2020 року.

Ключові слова: дослідницькі мережі; міжнародні організації; стратегічне планування; епістемічні спільноти.

\section{Видение, миссии и стратегии отдельных международных лесных исследовательских организаций}

\author{
А. Коллер ${ }^{1}$, Н. Вебер²
}

Каждая из лесных исследовательских организаций имеет видение и миссию, изложенные в их стратегии. Отдельным международным организациям по исследованию окружающей среды, таким как, например, Межправительственной научнополитической платформе по биоразнообразию и экосистемным услугам (МПБЭУ) не хватает видения и миссии. Отсутствие единого видения и миссии приводит к неодинаковым взглядам и ожиданиям среди различных экспертов, членов, партнеров и других заинтересованных сторон, участвующих в Платформе о том, что такое МПБЭУ, чего она пытается достичь и на чем она должна сосредоточиться. Это утверждение показывает, что видение и миссия является важным руководством к действию для сотрудников и других людей в организации, а также для общения с лицами, которые не принадлежат к организации.

Приводится сравнение текущих взглядов, миссий и стратегий трех международных организаций, занимающихся исследованиями лесов: Европейского института леса (EFI), Центра международных исследований леса (CIFOR) и Международного союза

\footnotetext{
Александра Коллер - аспирант магистерской программы лесных наук Технического университета в Дрездене, ул. Пиннер, 8, 01737 Тарандт, Германия. Тел.: +49-351-463-31811. E-mail: alexandra.koller@tu-dresden.de ORCID https://orcid. org/0000-0001-7072-4619

Норберт Вебер - профессор, доктор, профессор лесной политики и экономики лесных ресурсов Технического университета в Дрездене, ул. Пиннер, 8, 01737 Тарандт, Германия. Тел.: +49-351-463-31828, E-mail: norbert.weber@ tu-dresden.de ORCID https://orcid.org/0000-0001-7179-9364
}

лесных исследовательски организаций (IUFRO). На фоне теоретических концепций видений, миссий и стратегий применяются качественный контентанализ. Особое внимание уделяется тематическим областям работы организаций и их связям с областями развития (ЦУР).

Видение и миссия - важное руководство к действию для сотрудников международных организаций, а также для общения с людьми, не являющимися членами организации. В рамках стратегий некоммерческие организации могут определять свою миссию и видение, а также стратегические цели. Последние миссии и видения EFI, CIFOR и IUFRO анализируются с помощью текстового анализа.

Сравнение раскрывает различия между тремя направлениями в отношении общественного влияния и / или развития науки. Однако все они стремятся улучшить условия жизни людей. CIFOR четко фокусируется на ЦУР и сосредотачивается на них, в то время как IUFRO и EFI делают это только частично. За исключением удвоений, EFI и IUFRO совместно рассматривают 12 из 17 ЦУР. Этот вывод особенно важен в свете текущего сотрудничества между EFI и IUFRO. В 2019 году подписан Меморандум о взаимопонимании, в котором они утверждают, что обеспечивают достижение ЦУР.

Несмотря на работу по всему миру, IUFRO также сосредоточила свои усилия на науке. Что касается общения с лицами за пределами организации, то видение и миссия IUFRO, на первый взгляд, кажутся сосредоточенными на исследованиях только для исследователей и политиков. Однако более внимательное рассмотрение стратегии IUFRO показывает, что одна из пяти сфер исследований связана непосредственно с благосостоянием человека: «Леса для людей» с двумя из четырех приоритетных сфер, то есть (1) «Леса для средств существования» и (2) «Леса для качества жизни». Другие приоритетные области из оставшихся четырех косвенно связаны с благосостоянием людей, например, влияние изменения климата на лесные экосистемы и людей, зависимых от леса; использования лесных товаров и услуг; услуги экосистем; лесные экосистемы и водосбережение. Еще неизвестно, включит ли IUFRO свое социальное видение, сосредоточенное на действиях, в обновленную стратегию 2020 года.

Ключевые слова: исследовательские сети; международные организации; стратегическое планирование; эпистемические сообщества. 